\title{
FORMULASI DAN UJI EFEKTIVITAS KRIM ANTIBAKTERI EKSTRAK ETANOL DAUN BELUNTAS (Pluchea indica Less.) TERHADAP BAKTERI Propionibacterium acnes
}

\author{
Eunike Suru $^{1)}$, Paulina V.Y Yamlean ${ }^{1)}$, Widya Astuty Lolo ${ }^{1)}$ \\ ${ }^{1)}$ Program Studi Farmasi FMIPA UNSRAT Manado, 95115
}

\begin{abstract}
Beluntas plants contain flavonoid compounds, which are know to have antibacterial activity. This study aims to make a formulate and test the physical stability of antibacterial cream prepared from Beluntas Leaf extract (Pluchea indica Less.) with three variations in extract concentrations of 5\%, $10 \%$ and $15 \%$, and test the effectiveness of antibacterial against Propionibacterium acnes bacteria. The method of this research is experimental laboratory research. Beluntas leaves extract (Pluchea indica Less.) was obtained by maceration using $96 \%$ of ethanol and formulated into cream preparations with various extract concentrations. The result showed that Beluntas Leaf extract cream fulfilled the requirements of the physical properties of cream preparations, which included organoleptic test, homogeneity, $\mathrm{pH}$, dispersion, adhesion, emulsion type and cycling test. On the result of antibacterial activity testing, the average diameter of the clear zone of prepared cream of Beluntas leaf extract was at concentration of 5\%, 10\% and 15\%, respectively ie $6.16 \mathrm{~mm}, 7.83 \mathrm{~mm}, 10.16 \mathrm{~mm}$. Based on the classification of antibacterial category, the inhibiting ability of the test bacteria by 5\% and 10\% cream was categorized as moderate, and $15 \%$ was categorized as strongly which is the most effective cream inhibiting the activity of Propionibacterium acnes.
\end{abstract}

Keywords: Beluntas leaves, antibacterial cream, Propionibacterium acnes

\begin{abstract}
ABSTRAK
Tanaman Beluntas merupakan salah satu tanaman yang berkhasiat obat. Tanaman Beluntas mengandung senyawa flavonoid yang diketahui memiliki aktivitas antibakteri. Penelitian ini bertujuan untuk membuat formula dan uji stabilitas fisik sediaan krim antibakteri dari ekstrak Daun Beluntas (Pluchea indica Less.) dengan tiga variasi konsentrasi ekstrak yaitu 5\%, 10\% dan 15\%, serta menguji efektivitas antibakteri terhadap bakteri Propionibacterium acnes. Metode penelitian ini merupakan penelitian eksperimental laboratorium. Ekstrak daun Beluntas (Pluchea indica Less.) diperoleh dengan cara maserasi dengan pelarut etanol $96 \%$ dan diformulasikan menjadi sediaan krim dengan variasi konsetrasi ekstrak. Hasil penelitian menunjukkan bahwa krim ekstrak Daun Beluntas memenuhi persyaratan sifat fisik sediaan krim yang meliputi uji organoleptik, homogenitas, $\mathrm{pH}$, daya sebar, daya lekat, tipe emulsi dan cycling test .Pada hasil pengujian aktivitas antibakteri, diameter rata-rata zona bening sediaan krim ekstrak daun beluntas pada konsetrasi $5 \%, 10 \%$ dan $15 \%$ berturut -turut yaitu $6,16 \mathrm{~mm}, 7,83 \mathrm{~mm}, 10,16 \mathrm{~mm}$. Berdasarkan klasifikasi kekuatan daya antibakteri, maka kemampuan penghambatan bakteri uji oleh krim konsentrasi 5\% dan 10\% dikategorikan sedang, serta $15 \%$ dikategorikan kuat yang merupakan krim paling efektif menghambat aktivitas bakteri Propionibacterium acnes.
\end{abstract}

Kata kunci : Daun Beluntas, krim antibakteri, Propionibacterium acnes. 


\section{PENDAHULUAN}

Indonesia memiliki beraneka ragam tanaman yang diyakini oleh masyarakat dapat menyembuhkan penyakit. Dalam tanaman ada banyak komponen kimia yang dapat digunakan sebagai obat yang disebut sebagai tumbuhan berkhasiat obat. Masyarakat Indonesia telah lama menggunakan tumbuhan berkhasiat obat untuk menyembuhkan penyakit. Seiring berjalannya waktu pengetahuan tentang tumbuhan obat makin berkembang, kini tanaman obat telah digali manfaatnya. Pengetahuan tentang mengolah tumbuhan berkhasiat obat telah diwariskan secara turun temurun dari satu generasi ke generasi berikutnya. (Sibarani, 2013). Salah satu tanaman yang berkhasiat obat yang telah lama dikenal oleh masyarakat Indonesia sejak dahulu, yaitu tanaman Beluntas.

Salah satu tanaman yang berkhasiat obat yang telah lama dikenal oleh masyarakat Indonesia sejak dahulu, yaitu tanaman Beluntas. Beluntas umumnya tumbuh liar di daerah kering pada tanah yang keras dan berbatu, atau ditanam sebagai tanaman pagar. Daun beluntas mengandung alkaloid, flavonoid, tanin, minyak atsiri, natrium, kalium, aluminium, kalsium, magnesium, dan fosfor. Sedangkan akarnya mengandung flavonoid dan tannin. Daun Beluntas berbau khas aromatis dan rasanya getir, berkhasiat untuk meningkatkan nafsu makan (stomatik), penurun demam (antipiretik), peluruh keringat (diaforetik), penyegar, TBC kelenjar, nyeri pada rematik dan keputihan (Dalimartha, 1999).

Penelitian dan menunjukkan bahwa Daun Beluntas memiliki aktivitas antibakteri karena adanya senyawa flavonoid, hasil penelitian yang dilakukan oleh Anggita (2015), diketahui bahwa ekstrak Daun Beluntas dapat menghambat pertumbuhan bakteri Propionibacterium acnes pada konsetrasi $1 \%$ sebesar $9 \mathrm{~mm}$.

Propionibacterium acnes merupakan salah satu bakteri penyebab Jerawat. Bakteri ini tidak patogen pada kondisi normal, tetapi bila terjadi perubahan kondisi kulit, maka bakteri tersebut berubah menjadi invasif. Sekresi kelenjar keringat dan kelenjar sebasea menghasilkan air, asam amino, urea, garam dan asam lemak yang menjadi sumber nutrisi bagi bakteri. Bakteri ini berperan pada proses kemotaktik inflamasi dan pembentukan enzim lipolitik pengubah fraksi sebum menjadi massa padat, yang menyebabkan terjadinya penyumbatan pada saluran kelenjar sebasea (Jawetz,2000).

Berdasarkan latar belakang tersebut maka peneliti tertarik untuk melakukan penelitian tentang formulasi dan uji efektivitas antibakteri krim ekstrak Daun Beluntas terhadap bakteri Propionibacterium acnes. Bentuk sediaan krim lebih disukai oleh masyarakat karena mudah dibersihkan dan mudah menyebar (Ansel, 1989). Penggunaan sediaan krim juga dapat memberikan efek dingin, mengkilap dan melembabkan kulit. Sediaan krim tipe M/A dibuat dengan cara mendispersikan minyak dan air. Keunggulan kim tipe M/A yaitu memberikan efek yang optimum karena mampu menaikkan gradien konsentrasi zat aktif yang menembus kulit sehingga absorbsi perkutan menjadi meningkat (Engelin,2013). Keuntungan sediaan krim antara lain lebih mudah diaplikasikan, lebih nyaman digunakan pada wajah tidak lengket dan mudah dicuci dengan air (Sharon et al, 2013).

\section{METODE PENELITIAN Waktu dan Tempat Penelitian}

Penelitian ini dilaksanakan pada bulan November 2018 - April 2019 di Laboratorium Penelitian Farmasi Lanjut Program Studi Farmasi dan Laboratorium 
Biologi Dasar Fakultas Matematika dan Ilmu Pengetahuan Alam Universitas Sam Ratulangi Manado.

\section{Bentuk Penelitian}

Penelitian yang dilakukan bersifat eksperimental laboratorium.

\section{Alat dan Bahan}

a. Alat

Alat-alat yang digunakan dalam penelitian ini ialah, Erlenmeyer (Pyrex®), tabung reaksi (Iwaki Asahi glass®), kertas saring, oven (Infus HT), blender (Philips), batang pengaduk, gelas ukur, corong, gelas kimia (pyrex), timbangan analitik (AE Adam $\left.{ }^{\circledR}\right)$, hot plate (Nesco®Lab), ayakan (Eckhardt), lumpang dan alu, inkubator (Ecocell), Laminar Air Flow (LAF), cawan petri, $\mathrm{pH}$ meter (Elmetron), autoklaf (ALP), pipet mikro (eccopipette ${ }^{\mathrm{TM}}$ ), pot krim, sudip, mistar, jangka sorong, pecadang, jarum ose, pingset, spritus, kamera.

\section{b. Bahan}

Bahan-bahan yang digunakan yaitu daun Beluntas, Etanol 96\%, Nutrien Agar (NA), asam stearat, adeps lanae, nipagin, nipasol, paraffin cair, TEA, aquades, krim Klindamisin, $\mathrm{H}_{2} \mathrm{SO}_{4}, \quad \mathrm{BaCl}_{2} \cdot \mathrm{H}_{2} \mathrm{O} \quad 1,175 \%$, $\mathrm{NaCl} 0,9 \%$, alumunium foil. Bakteri yang digunakan yaitu Propionibacterium acnes.

\section{Prosedur Penelitian}

\section{Ekstraksi}

Proses ekstraksi dilakukan dengan menggunakan metode maserasi. Serbuk daun Beluntas ditimbang sebanyak $200 \mathrm{~g}$ dimasukkan dalam wadah, ditambahkan larutan etanol $96 \%$ sebanyak $800 \mathrm{~mL}$, dengan perbandingan $1: 4$, selanjutnya ditutup dengan penutup wadah didiamkan selama 5 hari sambil sesekali diaduk. Setelah 5 hari ekstrak disaring dengan menggunakan kertas saring dan menghasilkan filtrat I dan residu I. Residu yang ada kemudian diremaserasi dengan pelarut etanol 96\% sebanyak $600 \mathrm{~mL}$ dengan perbandingan 1:3, ditutup dengan penutup wadah didiamkan selama 2 hari sambil sesekali diaduk. Setelah 2 hari, sampel disaring sehingga menghasilkan filtrat 2 dan residu 2. Filtrat 1 dan filtrat 2 digabungkan lalu dievaporasi menggunakan alat evaporator kemudian dimasukkan dalam oven dengan suhu $40^{\circ} \mathrm{C}$ selama 2 hari, sehingga diperoleh ekstrak kental. Ekstrak kemudian ditimbang dan diperoleh sebanyak 17,8 gram ekstrak kental. Ekstrak kental kemudian disimpan dalam wadah gelas tertutup sebelum digunakan untuk pengujian.

\section{Formulasi dan Pembuatan Krim Ekstrak daun Beluntas \\ Pada penelitian ini dibuat sediaan krim ekstrak etanol daun Beluntas dengan tiga variasi konsentrasi, yaitu 5\%,10\% dan $15 \%$ dapat dilihat pada Tabel 1.}

\begin{tabular}{cccc}
\hline Komponen & Konsentrasi & Konsentrasi & Konsentrasi \\
& $5 \%$ & $10 \%$ & $15 \%$ \\
\hline Ekstrak daun Beluntas & $2,5 \mathrm{~g}$ & $5 \mathrm{~g}$ & $7,5 \mathrm{~g}$ \\
Asam stearate & $7,25 \mathrm{~g}$ & $7,25 \mathrm{~g}$ & $7,25 \mathrm{~g}$ \\
TEA & $0,75 \mathrm{~g}$ & $0,75 \mathrm{~g}$ & $0,75 \mathrm{~g}$ \\
Adeps lanae & $1,5 \mathrm{~g}$ & $1,5 \mathrm{~g}$ & $1,5 \mathrm{~g}$ \\
Parrafin Cair & $12,5 \mathrm{~g}$ & $12,5 \mathrm{~g}$ & $12,5 \mathrm{~g}$ \\
Nipagin & $0,05 \mathrm{~g}$ & $0,05 \mathrm{~g}$ & $0,05 \mathrm{~g}$ \\
Nipasol & $0,025 \mathrm{~g}$ & $0,025 \mathrm{~g}$ & $0,025 \mathrm{~g}$
\end{tabular}




\section{Aquades ad \\ Pembuatan Krim \\ Cara pembuatan yakni semua bahan} yang digunakan ditimbang terlebih dahulu sesuai dengan formulasi. Basis krim yang dibuat terdiri dari dua fase, yaitu fase minyak (paraffin cair,adeps lanae, asam stearat dan nipasol) dan fase air (Aquades, TEA, nipagin). Fase-fase tersebut dipanaskan pada suhu $70^{\circ} \mathrm{C}$ ditangas air. Fase minyak dipindahkan ke dalam lumpang yang telah berisi fase air diaduk hingga terbentuk massa krim,ekstrak kental daun Beluntas konsentrasi 5\% dimasukkan ke dalam basis krim diaduk sampai homogen kemudian disimpan dalam wadah krim. Untuk pembuatan krim dengan konsentrasi $10 \%$ dan 15\% dilakukan dengan cara yang sama dengan pembuatan krim ekstrak etanol daun Beluntas. Setelah itu, di

\section{Evaluasi sediaan Krim Ekstrak daun Beluntas}

Pengujian stabilitas sediaan krim ekstrak daun Beluntas menggunakan beberapa jenis pengujian yang merupakan persyaratan kelayakan sediaan krim diantaranya adalah :

a. Uji Organoleptis

Pemeriksaan ini bertujuan untuk mengamati ada tidaknya perubahan bentuk, warna dan bau. Krim yang baik adalah krim yang memiliki ciri organoleptis warna putih, tidak berubah warna, basis dan bau dalam penyimpanan (Ansel,1989).

b. Uji pH

Krim yang akan diamati disiapkan, kemudian diukur pHnya menggunakan $\mathrm{pH}$ meter, dimana $\mathrm{pH}$ krim harus sesuai dengan pH kulit yaitu 4,5-6,5 (Tranggono dan Latifa, 2007).

c. Uji daya sebar

Ditimbang 1 gram krim, diletakkan di tengah cawan petri yang berada dalam posisi terbalik. Diletakkan sekeping objek transparan yang lain diatas krim, dibiarkan 1
50

50

menit. Kemudian ditambahkan 200 gram beban tambahan, didiamkan 1 menit. Dicatat diameter krim yang menyebar. Daya sebar yang baik yaitu 5,6-6,4 cm (Rajalakshmi,2009).

d. Uji Homogenitas

Uji Homogenitas dilakukan dengan meletakkan krim secukupnya diantara dua kaca objek, kemudian diamati adanya butiran kasar atau tidak (Setiawati, 2014).

e. Uji Daya Lekat

Uji daya lekat dilakukan dengan cara 0,5 g krim diletakkan diatas dua gelas objek yang telah ditentukan, kemudian ditekan dengan beban $250 \mathrm{~g}$ selama 5 menit. Setelah itu dipasang objek gelas pada alat uji lalu ditambahkan beban $80 \mathrm{~g}$ pada alat uji. Kemudian dicatat waktu yang dibutuhkan beban tersebut untuk memisahkan kedua kaca tersebut (Sikawin,2018).

f. Uji Tipe Emulsi

Uji tipe emulsi menggunakan metode pengenceran. Krim yang telah dibuat dimasukkan kedalam gelas kimia kemudian diencerkan dengan aquadest, jika emulsi tidak tercampur dengan air maka tipe emulsinya $\mathrm{A} / \mathrm{M}$, jika tercampur dengan air maka tipe emulsinya M/A (Farida et al,2016).

\section{g. Cycling Test}

Salah satu cara mempercepat evaluasi kestabilan fisik adalah dengan metode dengan cycling test ini dilakukan sebanyak 6 siklus. Sediaan krim disimpan pada suhu dingin \pm $4^{0} \mathrm{C}$ selama 12 jam lalu dikeluarkan dan ditempatkan pada suhu $\pm 40^{\circ} \mathrm{C}$. proses ini dihitung 1 siklus. Kondisi fisik krim dibandingkan selama percobaan dengan sediaan sebelumnya (Dewi, 2010).

\section{Pengujian Aktivitas Antibakteri}

Uji aktivitas antibakteri terhadap krim ekstrak Etanol daun Beluntas menggunakan bakteri Propionibacterium acnes dengan cara 
difusi agar. 3 sumuran untuk setiap konsentrasi krim ekstrak Etanol daun Beluntas 5\%, 10\% dan 15\% dan dua sumuran lain untuk kontrol positif (krim klindamisin) dan kontrol negatif (basis krim).

HASIL DAN PEMBAHASAN

\section{HASIL}

Tabel 2. Hasil Uji Organoleptik Krim Ekstrak Etanol Daun Beluntas

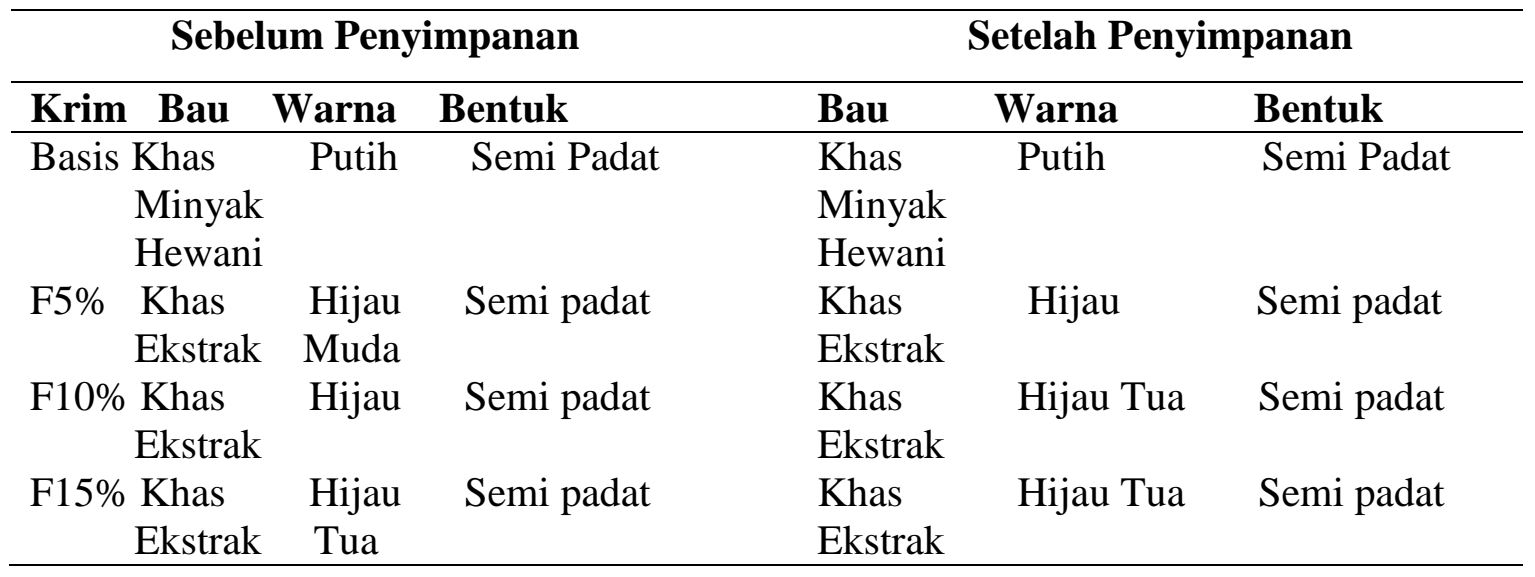

Tabel 3. Hasil Uji Homogenitas Krim Ekstrak Daun Beluntas

\begin{tabular}{lcc}
\hline & Sebelum Penyimpanan & Setelah Penyimpanan \\
\hline Krim & Homogenitas & Homognenitas \\
\hline Basis & Homogen & Homogen \\
F5\% & Homogen & Homogen \\
F10\% & Homogen & Homogen \\
F15\% & Homogen & Homogen \\
& & \\
\hline
\end{tabular}

Tabel 4. Hasil Uji pH Krim Ekstrak Etanol Daun Beluntas

\begin{tabular}{lcc}
\hline \multicolumn{2}{c}{ Sebelum Penyimpanan } & Setelah Penyimpanan \\
\hline Krim & Ph & pH \\
\hline Basis & 6,05 & 5,88 \\
F5\% & 5,74 & 5,68 \\
F10\% & 5,77 & 5,54 \\
F15\% & 5,56 & 5,48 \\
\hline
\end{tabular}

Tabel 5. Hasil Uji Daya Sebar Krim Ekstrak Etanol Daun Beluntas

\begin{tabular}{lcl}
\hline & Sebelum Penyimpanan & \multicolumn{1}{c}{ Setelah Penyimpanan } \\
\hline Krim & Diameter Sebar Krim & Diameter Sebar Krim \\
\hline
\end{tabular}




\begin{tabular}{lll}
\hline Basis & $6,0 \mathrm{~cm}$ & $6,2 \mathrm{~cm}$ \\
F5\% & $5,7 \mathrm{~cm}$ & $5,9 \mathrm{~cm}$ \\
F10\% & $5,6 \mathrm{~cm}$ & $5,8 \mathrm{~cm}$ \\
F15\% & $5,6 \mathrm{~cm}$ & $6,0 \mathrm{~cm}$ \\
\hline
\end{tabular}

Tabel 6. Hasil Uji Daya Lekat Krim Ekstrak Etanol Daun Beluntas

\begin{tabular}{llc}
\hline & Sebelum Penyimpanan & Setelah Penyimpanan \\
\hline Krim & Waktu & Waktu \\
\hline Basis & 9,23 detik & 8,05 detik \\
F5\% & 8,04 detik & 6,07 detik \\
F10\% & 6,11 detik & 5,35 detik \\
F15\% & 5,40 detik & 4,45 detik \\
\hline
\end{tabular}

Tabel 7. Pengujian Tipe Emulsi Krim Ekstrak Etanol Daun Beluntas

\begin{tabular}{lcl}
\hline & Sebelum Penyimpanan & Setelah Penyimpanan \\
\hline Krim & Tipe Emulsi & Tipe Emulsi \\
\hline Basis & Minyak dalam Air & Minyak dalam Air \\
F5\% & Minyak dalam Air & Minyak dalam Air \\
F10\% & Minyak dalam Air & Minyak dalam Air \\
F15\% & Minyak dalam Air & Minyak dalam Air \\
\hline
\end{tabular}

Tabel 8. Hasil Pegujian Mikrobiologi Krim Ekstrak Etanol Daun Beluntas

\begin{tabular}{lcccc}
\hline Formulasi & \multicolumn{3}{c}{ Diameter daerah hambatan (mm) } \\
\hline & Ulangan I & Ulangan & Ulangan & Rata-rata \\
& I & II & III & \\
\hline K (-) & 0 & 0 & 0 & 0 \\
K (+) & 25,00 & 25,00 & 25,00 & 25,00 \\
F5\% & 5,00 & 6,50 & 7,00 & 6,16 \\
F10\% & 8,50 & 8,00 & 7,00 & 7,83 \\
F15\% & 10,00 & 10,50 & 10,00 & 10,16 \\
\hline
\end{tabular}

\section{PEMBAHASAN}

Penelitian ini dilakukan dengan memformulasikan sediaan krim antibakteri dengan menggunakan ekstrak daun dari Tanaman Beluntas. Tanaman Beluntas mengandung senyawa alkaloid, flavonoid, tanin, minyak atsiri, natrium, kalium, alumunium, kalsium, magnesium dan fosfor.
Tanaman Beluntas memiliki sifat antibakteri karena adanya senyawa flavonoid (Purnomo, 2001).

Proses awal daun Beluntas dibuat menjadi simplisia dengan cara pengeringan sampel. Proses pengeringan ini bertujuan untuk menurunkan kadar air dalam daun Beluntas, mengurangi kadar air juga dapat 
mencegah reaksi enzimatik dimana kandungan kimia yang terkandung dalam bahan diubah menjadi produk lain atau dirusak oleh enzim. Ekstraksi terhadap serbuk simplisia daun Beluntas dilakukan dengan menggunakan ekstraksi cara dingin, yaitu metode maserasi.. Proses ekstraksi dilakukan dengan menggunakan pelarut Etanol 96\% karena pelarut ini menyari hampir keseluruhan kandungan simplisia baik non polar,semi polar maupun polar (Iswanti,2009). Pelarut ini bersifat selektif, tidak beracun dan bersifat universal yang cocok untuk mengekstrak semua golongan senyawa metabolit sekunder (Kristanti et $a l, 2008)$.

Pengujian stabilitas fisik terhadap Sediaan Krim Ekstrak Etanol Daun Beluntas pada konsetrasi berbeda yaitu 5\%, 10\% dan $15 \%$. Pengujian ini meliputi uji organoleptik, uji homogenitas, uji $\mathrm{pH}$,daya sebar, daya lekat, tipe emulsi dan cycling test. Pengujian fisik ini bertujuan untuk melihat stabilitas dan kelayakan suatu sediaan.

Pengujian organoleptik meliputi bentuk, warna dan bau. Hasil pengamatan menunjukkan bahwa semua formulasi krim yang dihasilkan berbentuk semipadat karakteristik dari krim pada umumnya, berwarna dan memiliki bau khas Tanaman Beluntas. Semakin tinggi penambahan konsentrasi ekstrak daun Beluntas, maka semakin kuat bau yang dihasilkan dan warna krim berubah. Hal ini tampak dari perubahan warna dari krim, semakin tinggi kadar konsetrasi yang terkandung, maka warna krim akan semakin hijau. Begitu pula halnya dengan bau khas Tanaman Beluntas yang tercium dari krim konsetrasi 5\%, 10\% dan $15 \%$. Semakin tinggi konsentrasi, maka semakin tercium bau khas Tanaman Beluntas. Setelah dilakukan penyimpanan terjadi perubahan warna pada sediaan krim dari warna hijau muda menjadi hijau gelap ini dapat diartikan bahwa krim ekstrak daun Beluntas memiliki stabilitas yang tidak baik dalam penyimpanan. Namun bentuk dan bau dari krim tetap sama pada waktu sebelum penyimpanan dan sesudah penyimpanan.

Pengujian homogenitas bertujuan untuk melihat dan mengetahui tercampurnya bahan-bahan sediaan krim sehingga tidak terlihat adanya butiran-butiran kasar. Pengujian dilakukan terhadap basis krim dan krim ekstrak daun Beluntas konsentrasi 5\%, $10 \%$ dan $15 \%$. Hasil pengamatan pada basis krim sebelum dan setelah penyimpanan menunjukkan susunan yang homogen dan dari ketiga formulasi sediaan krim daun Beluntas sebelum dan sesudah penyimpanan menunjukkan susunan yang homogen ( tidak adan butiran kasar) Hal ini sesuai dengan persyaratan homogenitas krim yaitu menunjukkan susunan yang homogen serta tidak adanya butiran kasar pada krim (Anonim, 1986).

Pengujian $\mathrm{pH}$ pada krim untuk mengetahui kadar asam dan basa dari sediaan krim. Nilai $\mathrm{pH}$ untuk sediaan topikal harus sesuai dengan $\mathrm{pH}$ kulit yaitu 4,5-6,5. Pengujian $\mathrm{pH}$ pada sediaan krim menggunakan $\mathrm{pH}$ meter dengan memasukkan alat $\mathrm{pH}$ meter kedalam krim yang telah dibuat .Hasil pengukuran $\mathrm{pH}$ krim sebelum penyimpanan didapatkan hasil untuk basis krim 6,05, krim dengan konsentrasi 5\% niali pH 5,74, krim dengan konsentrasi $10 \%$ nilai pH 5,77 dan untuk krim dengan konsentrasi $15 \%$ nilai $\mathrm{pH} 5,56$. Pengukuran $\mathrm{pH}$ setelah penyimpanan krim untuk basis krim 5,88 konsentrasi $5 \%$ niali $\mathrm{pH} 5,68$, konsentrasi $10 \%$ nilai $\mathrm{pH} 5,54$, konsentrasi $15 \%$ nilai $\mathrm{pH}$ 5,48 dan terjadi penurunan $\mathrm{pH}$ setelah penyimpanan namun masih sesuai dengan persyaratan $\mathrm{pH}$ sediaan yaitu 4,5-6,5 sehingga aman digunakan pada kulit.

Pengujian daya sebar merupakan pengujian yang dilakukan untuk mengetahui 
kemampuan penyebaran krim pada permukaan kulit dimana diharapkan krim mampu menyebar dengan mudah pada saat diaplikasikan pada permukaan kulit. Daya sebar 5-7 cm menunjukkan konsistensi yang sangat nyaman dalam penggunaan (Garg et al, 2002). .Hasil pengujian daya sebar untuk sediaan krim sebelum dilakukan penyimpanan, basis krim $6,0 \mathrm{~cm}$, konsentrasi $5 \% 5,7 \mathrm{~cm}$, konsentrasi $10 \% 5,6 \mathrm{~cm}$ dan konsetrasi $15 \%$ yaitu $5,6 \mathrm{~cm}$. Hasil pengujian daya sebar krim setelah dilakukan penyimpanan untuk basis krim $6,2 \mathrm{~cm}$ konsentrasi 5\% 5,9 cm, konsentrasi 10\% 5,8 $\mathrm{cm}$ dan untuk konsentrasi 15\% 6,0 cm . Dari hasil uji daya sebar sebelum dan sesudah penyimpanan dengan menggunakan beban yang sama terjadi perubahan yaitu daya sebar meningkat sesudah penyimpanan hal ini terjadi karena perubahan viskositas dapat merubah daya penyebaran, semakin menurun viskositas maka semakin besar daya penyebarannya.

Pengujian daya lekat sediaan krim ekstrak daun Beluntas dilakukan untuk mengetahui waktu yang dibutuhkan krim tersebut untuk melekat pada kulit. Daya lekat yang baik memungkinkan krim tidak mudah lepas dan semakin lama melekat pada kulit, sehingga dapat menghasilkan efek yang diinginkan. Persyaratan daya lekat yang baik untuk sediaan topikal adalah lebih dari 4 detik (Rachmalia et al, 2016). Hasil pengukuran daya lekat krim ektsrak daun Beluntas pada tiga variasi konsentrasi sebelum dan sesudah penyimpanan memenuhi syarat topikal yang baik.

Pengujian tipe emulsi menggunakan metode pengenceran dengan cara mengencerkan 1 g krim kedalam $100 \mathrm{~mL}$ aquadest dan diaduk hingga homogen, apabila krim tersebut larut dalam aquades maka tipe krim ini yaitu minyak dalam air (M/A). Hal ini disebabkan karena jumlah fase terdispersi (minyak/lemak) yang digunakan dalam krim lebih kecil dari fase pendispersi (fase air), sehingga fase minyak akan terdispersi merata ke dalam fase air dan membentuk emulsi minyak dalam air dengan bantuan emulgator.

Metode yang digunakan untuk uji aktivitas antibakteri adalah difusi agar menggunakan sumuran dengan media Nutrien Agar (NA). Metode ini dilakukan untuk mengetahui besarnya diameter zona bening pada bakteri Propionibacterium acnes setelah inkubasi selama 24 jam. Daya hambat menurut Davis dan Stout (1971) terbagi atas : sangat kuat (zona hambat > 20mm), kuat (zona hambat 10-20 mm), sedang (zona hambat 5-10 $\mathrm{mm}$ ) dan lemah (zona hambat $<5 \mathrm{~mm}$ ). Pengujian aktivitas antibakteri ditentukan berdasarkan diameter zona hambat disekitar pencadang yang berisi larutan uji. Pengujian krim ekstrak daun Beluntas dengan konsentrasi 5\%, 10\% dan $15 \%$ menunjukan aktivitas antibakteri dengan terbentuknya zona hambat disekitar sumuran. Diameter zona hambat diukur menggunakan jangka sorong dengan cara mengukur secara horizontal dan vertikal dan hasil yang didapatkan dikurangi diameter sumuran sebesar $7 \mathrm{~mm}$. Krim dengan ekstrak daun Beluntas konsentrasi 5\% memberikan daya hambat sedang dengan zona hambat $6,16 \mathrm{~mm}$. Krim ekstrak daun Beluntas konsentrasi 10\% memberikan daya hambat sedang dengan zona hambat $7,83 \mathrm{~mm}$, dan untuk Krim ekstrak daun Beluntas konsentrasi 15\% memberikan daya hambat kuat dengan zona hambat 10,16 mm. Kontrol positif memberikan daya hambat kuat dengan zona hambat 25,00 $\mathrm{mm}$ dan kontrol negatif tidak memberikan daya hambat karena menghasilkan zona hambat $0 \mathrm{~mm}$. Dari hasil tersebut dapat dilihat bahwa krim ekstrak daun Beluntas dengan konsentrasi 5\%, 10\% dan $15 \%$ dapat menghambat aktivitas bakteri Propionibacterium acnes. Pada penelitian 
sebelumnya, hasil uji antibakteri ekstrak etanol daun Beluntas, mempunyai KHM 1\% yaitu $9 \mathrm{~mm}$. Pada sediaan krim yang telah dibuat, krim yang sudah dicampur dengan ekstrak etanol daun Beluntas memiliki daya hambat namun semakin menurun dibandingkan dengan ekstrak etanol daun Beluntas. Hal ini disebabkan karena basis sulit berdifusi sehingga zat aktif tidak dapat lepas dengan baik dari basis sehingga daya hambat terhadap bakteri semakin menurun. Adanya zona hambat yang terbentuk pada kim ekstrak daun Beluntas karena adanya senyawa antibakteri pada daun Beluntas.Senyawa tersebut merupakan senyawa flavonoid. Mekanisme kerja flavonoid sebagai antibakteri adalah membentuk senyawa kompleks dengan protein ekstraseluler dan terlarut sehingga dapat merusak membran sel bakteri dan diikuti dengan keluarnya senyawa intraseluler (IndoBIC, 2005 dalam Nuria et al, 2009). Sitoplasma dalam sel dibatasi oleh membran sitoplasma, yang berperan sebagai barrier permeabilitas selektif fungsi transport aktif dan kemudian mengontrol komposisi internal sel. Jika fungsi integritas sel membrane sitoplasma dirusak, makromolekul dan ion keluar dari sel, kemudian sel rusak atau terjadi kematian (Brooks et al, 2005).

Analisis data dapat dilakukan dengan menggunakan uji statistic one way ANOVA dengan tujuan sebagai dasar pengambilan keputusan dari suatu hipotesis. Hasil uji one way ANOVA pada penelitian ini yaitu menunjukkan adanya perbedaan antar perlakuan sig $(0,000)<(0,05)$ artinya $\mathrm{P}$-value $<\alpha(0,05)$, maka $\mathrm{H}_{0}$ ditolak $\mathrm{H}_{1}$ diterima. Maka terdapat perbedaan signifikan zona bening antara basis krim dan krim ekstrak Etanol daun Beluntas konsentrasi 5\%, 10\% dan $15 \%$. Pengujian dilanjutkan dengan uji Duncan untuk melihat perlakuan mana yang memberikan efek berbeda atau tidak jauh berbeda. Dan didapatkan hasil menunjukkan perbedaan yang signifikan untuk aktivitas antibakteri pada konsentrasi 5\%, 10\%, 15\% dan untuk konsentrasi $15 \%$ dengan kontrol positif didapatkan hasil yang juga signifikan, maka diperoleh hasil bahwa setiap konsentrasi memiliki aktivitas antibakteri tetapi yang paling efektif digunakan ialah krim ekstak etanol daun Beluntas konsentrasi 15\%.

\section{KESIMPULAN}

Berdasarkan hasil penelitian dapat disimpulkan bahwa :

1.Ekstrak etanol daun Beluntas dapat diformulasikan menjadi sediaan krim antibakteri dengan konsentrasi 5\%, 10\% dan $15 \%$ yang telah memenuhi syarat pengujian organoleptik, homogenitas, $\mathrm{pH}$, daya sebar, daya lekat, tipe emulsi dan cycling test.

2. Sediaan Krim ekstrak Etanol daun Beluntas dapat memberikan efek antibakteri terhadap bakteri Propionibacterium acnes dengan zona hambat pada konsentrasi $5 \%$ $6,16 \mathrm{~mm}$, konsentrasi $10 \%$ 7,83 $\mathrm{mm}$ yang termasuk kategori daya hambat sedang, konsentrasi 15\% 10,16 mm dikategorikan kuat yang merupakan krim paling efektif menghambat aktivitas bakteri Propionibacterium acnes.

\section{SARAN}

Perlu dilakukan penelitian lagi untuk pengujian ditambahkan uji lainnya seperti uji viskositas terhadap sediaan krim agar dapat memenuhi semua parameter uji kualitas.

\section{DAFTAR PUSTAKA}

Anggita,R.H.,Tri, C., Toni, S.,dan Rahayu, I, L.2015. Uji aktivitas antibakteri ekstrak daun Beluntas (Pluchea indica (L.)) terhadap bakteri Propionibacterium acnes penyebab 
Jerawat. UINSGD Bandung .(9):141144.

Anonim.1986. Sediaan Galenika. Departemen

Kesehatan Republik Indonesia,Jakarta.

Ansel, H. 1989. Pengantar Bentuk Sediaan

Farmasi Edisi ke-4. UI Press, Jakarta.

Brooks,J.S.Butel.,S.A.Morse.2007.

Mikrobiologi Kedokteran.Salemba

Medika,Jakarta.

Dalimartha, S. 1999. Atlas Tumbuhan Obat Jilid I. Trubus Agriwidya,Jakarta.

Davis, W.W., Stout, T.R. 1971. Disc plate method of microbiological assay. Journal of microbiology. 22(4):659665.

Dewi,R.K.2010. Optimasi Formulasi Mikroemulsi Sediaan Hormon Testosteron Undekanoat [Skripsi]. Universitas Negeri Islam Negeri Syarif Hidayatullah,Jakarta.

Engelin.2013. Optimasi Krim Sarang Burung Walet Puth Tipe M/A Dengan Variasi Emulgator Sebagai Pencerah Kulit Menggunakan Simplex Lattice Design. [Skripsi].Fakultas Kedokteran Universitas Tanjungpura, Pontianak.

Farida, Y., N., Nushalati., T., Qoriatul,. A.2016. Formulasi dan Uji Stabilitas Fisik Krim Susu Kuda Sumbawa dengan Emulgator Non Ionik dan Anionik.Jurnal JF FIK UINAM.(4):4.

Garg, A., Aggarwal, D., Garg, S., Sigla, A. K. 2002. Spreading of semisolid Formulation: An Update. Pharmaceutical Technology. 84:102.

Iswanti,D.A. 2009.Uji aktivitas antibakteri Fraksi N-heksan,Fraksi Etil Asetat dan Fraksi Etanol 96\% Daun Ekor Kucing (Achalypha Hispida Burn. F) terhadap bakteri Staphylococcus aureus ATCC 25923 secara Dilusi [Skripsi]. Fakultas Farmasi Universitas Setia Budi, Surakarta.

Jawetz, E., Melnick, J. L., and Adelberg, E. A., 2000. Mikrobiologi Kedokteran. Bagian Mikrobiologi Fakultas Kedokteran, Universitas Airlangga, Salemba Medika, Jakarta.

Kristanti, A.N., Aminah.,M. Tanjung., B.,Kurniadi. 2008. Buku Ajar Fitokimia.Unair Press, Surabaya.

Nuria, Maulia Cut., A. Faizatun., Sumantri. 2009. Uji Aktivitas Antibakteri Ekstrak Etanol Daun Jarak Pagar (Jatropha curcas L) terhadap Bakteri Staphylococcus aureus ATCC 25923, Escherichia coli ATCC 25922, dan Salmonella typhi ATCC 1408.Mediagro. 5:(2):26- 37.

Purnomo,M. 2001.Isolasi Flavonoid dari Daun Beluntas (Pluchea indica (L).) yang Mempunyai Aktivitas Antimikroba [Skripsi]. Universitas Airlangga, Jakarta.

Rachmalia.,N,. Mukhlishah., I,. Sugihartini, N, Yuwono., T,. (2016). Daya iritasi dan sifat fisik sediaan salep minyak atsiri bunga cengkih (Syzigum aromaticum) pada basis hidrokarbon. Jurnal Majalah Farmaseutik.12:372376.

Rajalakshmi,G.N.2009. Formulation and Evaluation of Clotrimazole and Ichtammo Ointment. International Journal of Pharma and Bioscience.4:10-12.

Setiawati,E. 2014. Pengaruh Peningkatan Konsentrasi Setil Alkohol sebagai Pengental Terhadap stabilitas Fisik Krim Tipe M/A Ekstrak Rimpang Jahe Gajah (Zingiber Officinale Roscoe) [Skripsi]. Universitas Muhamadiyah, Jakarta. 
PHARMACON- PROGRAM STUDI FARMASI, FMIPA, UNIVERSITAS SAM RATULANGI,

Volume 8 Nomor 1 Februari 2019

Sharon,N.,Anam,S.,Yuliet,. 2013. Formulasi Krim Ekstrak Etanol Bawang Hutan (Eleutherine palmifolia L. (Merr). Online Jurnal of Natural Science. 2(3): 111-122.

Sibarani, R,V., Wowor, M,P,. Awaloei,H,. 2013. Uji efek analgesik ekstrak Daun Beluntas (Pluchea indica (L.) pada mencit (mus musculus). Jurnal e-Biomedik (eBM),(1)1:621-628.
Sikawin,M,.B. 2018. Formulasi Sediaan Gel Antibakteri Ekstrak Etanol Tanaman Sereh (Cymbopongon ciratus (DC.) Stapf ) dan uji aktivitas antibakteri (Staphylococcus aureus) secara in vitro [Skripsi]. Universitas Sam Ratulangi, Manado. 